\title{
Transitivity Analysis of Joe Biden's Inaugural Address From the Perspective of Systemic Functional Grammar
}

\author{
Qiujian Xiang \\ School of Foreign Languages and Literatures, Chongqing Normal University, Chongqing, China
}

\begin{abstract}
Halliday's Systemic Functional Grammar provides a new perspective and method for political discourse analysis. This paper first introduces the research status of political discourse at home and abroad, and then elaborates three metafunctions of Systemic Functional Grammar, namely ideational function, interpersonal function as well as textual function. On this basis, this paper makes an in-depth transitivity analysis of the inaugural address of the 46th president of the United States, Joseph Robinette Biden. Through profound research, this paper attempts to reveal how English language is applied to hide ideology in political speeches and how president Joe Biden uses various language features to persuade and inspire American people in order to reach his political purpose; at the same time, it also verifies the practicability of Systemic Functional Grammar in the analysis of political speech discourse.
\end{abstract}

Index Terms — systemic functional grammar, transitivity, Joe Biden, political speech, inaugural address

\section{INTRODUCTION}

On January 20, 2021, the president-elect of the United States, Joseph Robinette Biden (hereinafter Joe Biden or Biden), took the oath of office at the Capitol Hill in Washington D.C, which marked his transition from a democratic leader to the 46th U.S. president. After a brief ceremony, his inaugural address was delivered. As the oldest president in American history to be in office, Biden was faced with a variety of thorny issues left by the former president Donald Trump, such as economic recession, wide spread of COVID-19, social chaos and so on. Under such circumstances, Biden's inaugural address undoubtedly received huge attention from the global community. Based on the theory of metafunctions in the Systemic Functional Grammar, this paper makes a textual analysis of Joe Biden's inaugural address, aiming to explore the linguistic features of the speech as well as the political intention of Biden and his administration.

\section{LITERATURE REVIEW}

\section{A. Previous Studies of Political Speech Abroad}

Speech is a kind of language communicative activity in which the speaker publicly clarifies his or her views, attitudes as well as emotions on a specific issue or theme. In order to fully convince the audience, the speaker always combines his or her voiced language with a variety of paralinguistic behaviors, such as facial expressions, gestures and body movements. In addition, according to different criteria, speech can be divided into multiple types. For instance, when focusing on the content, speeches can be divided into political speech, life speech, academic speech, court speech, and even religious speech. And among those sorts of speeches, the political speech has always remained dominant in the field of discourse analysis.

In the late 20th century, a large number of prominent linguists began to focus on political speech analysis. Fairclough (1989) pointed out that discourse can be regarded as a political practice in his book Language and Power. In addition, he stressed that political speech was not only a struggle for power, but also a conflict between different ideologies. And as far as Wodak (1989) was concerned, language scholars should attach great importance to historical background when analyzing political speeches. Lakooff (1990) started his research from a completely different angle. He used conceptual metaphor as a main tool to prove that political discourse was a creative thinking pattern rather than a common linguistic phenomenon. In the book The Language of Politics, Beard (2000) elaborated British political discourses by means of Critical Discourse Analysis (CDA), and put forward some distinctive characteristics about British political speeches as well. When it comes to the 21 st century, some modern scholars have also put forward their own opinions on political discourse analysis. For instance, Hashim (2015) believed that politicians communicate directly with the general public with the aim to convince them of their plans or opinions. In his mind, often, the speakers on the stage would promote themselves and express their great potentials to be a good leader. Based on this point, the speech act analysis provides a good way for analyzing the politician's speeches. Therefore, he investigated the selected political speeches of John Kerry in Presidential Campaign in 2004 and George Bush's Inaugural address in 2001 based on the locution, illocutionary and perlocutionary speech acts. And Cabrejas-Penuelas (2020), a Spanish scholar, used an analytical 
framework for the identification of conceptual metaphors to make a comparative analysis of the economy sections of the 2015 State of the Union Address in the U.S. and the 2015 State of the Nation Debate in Spain. At the end of his paper, he indicated that both politicians used metaphors in an attempt to justify the current policy response to the economic crisis.

\section{B. Previous Studies of Political Speech at Home}

Quite a few Chinese scholars have also made solid contributions to political discourse analysis. Taking the speeches given by the leaders of China, the United States and Russia at the 70th Anniversary of the Founding of the UN as the object, Zhang Quanfeng (2016) analyzed both the similarities and differences of the intertextuality rhetoric strategies of those speeches, concluding that political speeches with the theme of "peaceful development" will become a prominent feature in the future. $\mathrm{Lu}$ Ying (2012) found that few people focused on the meta-discourse of political discourse in China, therefore, on the basis of the existing researches of meta-discourse, she used the Report on the Work of the Government 2012 as corpus, presenting both the indispensable position and the role of interpersonal meta-discourse in political discourse. In $2021, \mathrm{Zhang}$ Li \& Wang Shaohua (2021) integrated cognitive linguistics with pragmatics to analyze the structure, metaphor, pragmatic presupposition and pragmatic identity of Xi Jinping's opening address at Boao Forum for Asia in 2018. They found that with the theme of "a community with a shared future for mankind", based on a series of metaphorical words or expressions such as "friend" and "up and down", Xi's speech effectively activated metaphorical surface structures such as "journey" and promoted China's international influence to a large extent.

\section{THEORETICAL FRAMEWORK}

\section{A. M. A. K. Halliday and Systemic Functional Grammar}

M.A.K. Halliday, born in Leeds, Yorkshire, England, in 1925, was the founder of Systemic Functional Grammar and one of the most influential and outstanding linguists in the world. He inherited two basic principles from his tutor, J.R. Firth, the founder of the London School. Of the two theories, the first is "context of situation", which holds that language is closely related to and influenced by social situations. And the second principle refers to the concept of "system". After deep research, Halliday further developed the first principle and began to study language from the perspective of sociology. However, as for the second principle, he redefined the meaning of "system" and created a whole set of subcategories. And in order to make his theory as clear as possible, he proposed a set of theoretical models, which precisely defined both the meaning of various terms and their relationships. After that, he attached great importance to studying the functions of language and then put forward the well-known Systemic Functional Grammar. In 1985, the publication of An Introduction to Functional Grammar marked his Systemic Functional Grammar had become relatively mature and complete. In that book, in order to explain the complex internal structures of language, he introduced readers three metafunctions, namely, ideational function, interpersonal function and textual function. Generally speaking, the ideational function is used to describe things and express processes, the interpersonal function to language communication, while the textual function to information organization. (M.A.K. Halliday, 2008)

\section{B. An Introduction to Three Metafunctions}

\section{Ideational Function}

The ideational function refers to the expression of the speaker's experiences in reality and his or her inner world, that is to say, these experiences could reflect his or her linguistic acts and internal consciousness like cognition, perception and reaction. And it is mainly realized through the transitivity systems, which attempt to identify its associated participants and circumstances. According to Halliday, there are six processes of transitivity, namely, material process, mental process, behavioral process, relational process, verbal process and existential process.

To be specific, the material process, also known as action process, can be seen as a process of doing something, which often contains dynamic verbs like "make", "swim", "flow", "play", etc., an actor and a goal. In general, the actor often indicates the participant or subject while the goal refers to the object which is usually realized by pronouns("it", "them", etc.) or nominal groups("the house", "a book", "some breads", etc.). Example: Tom (actor) bought (the material process) a lot of books (goal) from the store.

The mental process refers to the process of one's perception, cognition and reaction. In other words, it describes one's psychological events rather than real action. So this process is often realized by verbs like "admire", "appreciate", "hate" and so on. Furthermore, there are two important components in the mental process, namely the senser (human beings or animate creatures) and phenomenon. Example: The great novelist(phenomenon) was admired (the mental process) by my brother Mike(sener).

The behavioral process refers to the physiological process such as crying, dreaming, laughing etc. Example: The little baby often cries (the behavioral process) at midnight.

The relational process reflects the relationships between two items or two notions, which can be divided into two types: attributive relational process (formula: "A is one of the properties of B") and identifying relational process (formula: "A is the identity of B"). And it's always demonstrated by verbs like "be", "become", "have", "stand for", etc. Example: Lily is (the relational process) a hard-working student in my class. 
The verbal process means a process of information changing through voiced speech, therefore, relevant verbs such as "talk", "speak", "tell" and "communicate" are always included in it. Example: Smith told (the verbal process) his father that he had overslept yesterday morning.

At last, the existential process indicates that something exists or happens, and the "there-be" pattern is a typical symbol of this process. Sometimes, verbs like "arise" and "stand for" are also included. Example: There is (the existential process) a river running around our village. (See Table 1)

TABLE 1

A SUMMARY OF THE TRANSITIVITY SYSTEMS

\begin{tabular}{|l|l|l|}
\hline Process & Meaning & Core Verbs \\
\hline the material process & a process of doing an event & make, swim, flow, play, etc. \\
\hline the mental process & a process of of one's perception, cognition and reaction & admire, appreciate, hate, etc. \\
\hline the behavioral process & a process of one's physiological state & cry, dream, laugh, breathe, etc. \\
\hline the relational process & a process of the relationships between two notions & be, become, have, etc. \\
\hline the verbal process & a process of information changing (usually through speech) & talk, speak, tell, communicate, etc. \\
\hline the existential process & something exists or happens & be, arise, etc. \\
\hline
\end{tabular}

\section{Interpersonal Function and Textual Function}

According to Halliday, apart from the function of expressing people's various experiences in outside and inner world, the language itself can also manifest speakers' identity, social status, values or even their evaluation and judgments towards something, which is regarded as its interpersonal function. And the interpersonal function is usually realized by two constituents: mood and modality. The first part mood includes the subject and the finite. Any noun or nominal group can be used as the subject, while the finite indicates some verbal operators expressing tense. As for the modality, it often refers to the judgment of the frequency, probability or willingness of the statement made by the speakers, which expresses the meaning of the language in a balanced way instead of sole yes or no. From Halliday's perspective, based on some unique characteristics, the modality can be further divided into modalization and modulation. In general, the first one is a process to exchange the proposition while the second one to exchange goods and services. In addition to the two metafunctions mentioned above, Halliday put forward the third one: textual function, which mainly focuses on the coherence and organization of the language and can be revealed by the theme-rheme system.

\section{The ANALysis of Transitivity IN JOE BidEN’s INAUgural AdDRESS}

\section{A. The Analysis of Material Process}

Example 1: "And now, a rise in political extremism, white supremacy, domestic terrorism that we must confront and we will defeat. To overcome these challenges -- to restore the soul and to secure the future of America -- requires more than words. It requires that most elusive of things in a democracy: Unity. Unity."

Example 2: "I ask every American to join me in this cause. Uniting to fight the common foes we face: anger, resentment, hatred, extremism, lawlessness, violence, disease, joblessness, hopelessness."

As is well known that the material process stands for a process of doing an event, which mainly contains two constituents, namely, an actor and a goal. Of the two parts, the actor is someone who performs the action while the goal is certainly the target of the action, which is usually represented by nouns or pronouns.

In the first example, President Joe Biden describes the current situation of America and issues his extremely strong appeal for unity. It is obvious that there are several material processes like "must confront", "overcome", "restore" and "requires". Besides, the actors in the example are "we" and "it", while the goals are "domestic terrorism", "these challenges", "the soul", "the future of America", etc. Through analysis, it could be concluded that Joe Biden uses these vivid material processes for the purpose of stressing the harshness of the current social environment and encouraging all American people to work together to fight for a brighter future.

In example 2, there are four material processes, namely, "join", "uniting", "fight" and "face". At the same time, he uses "every American" and "we" as actors and "me", "the common foes" as the goals, which undoubtedly shows Joe Biden's strong desire and wish to win people's supports. In his view, the only way to fight anger, resentment, hatred, extremism, lawlessness, violence, disease, joblessness, hopelessness is to cooperate with all common folks.

\section{B. The Analysis of Mental Process}

Example 3: "We can make America, once again, the leading force for good in the world. I know speaking of unity can sound to some like a foolish fantasy. I know the forces that divide us are deep and they are real. But I also know they are not new. Our history has been a constant struggle between the American ideal that we are all created equal and the harsh, ugly reality that racism, nativism, fear, and demonization have long torn us apart. The battle is perennial. Victory is never assured."

Example 4: "I believe we must and I believe we will. And when we do, we will write the next chapter in the American story. It's a story that might sound something like a song that means a lot to me." 
The mental process is a process of describing one's perception, cognition and even reaction. That is to say, it focuses on one's psychological events rather than body movements. And the most two important components in it are senser (human beings or animate creatures) and phenomenon.

The example 3 describes Joe Biden's objective recognition and judgments of the divided America. It is clear that the word "know" stands for the mental process, so there are three mental processes in total. Obviously, the senser is "I" and the phenomena are "speaking of unity can sound to some like a foolish fantasy", "the forces that divide us are deep and they are real" and "they are not new". Specifically speaking, Joe Biden uses three "know" to confess the deep-rooted social forces like racism and terrorism existing in the mainland, which depicts his calmness under great pressure to some extent.

In example 4, the words "believe" and "means" are symbols of mental process, the sensers are "I" and "the song", while the phenomena are "we must", "we will" and "a lot to me". In this paragraph, Joe Biden restates some initiatives he has put forward in the past and points out American people will surely live a more prosperous life under his leadership.

\section{The Analysis of Relational Process}

Example 5: "This is America's day; this is democracy's day: a day of history and hope; of renewal and resolve."

The relational process reflects the relationships between two items or two notions, which is often demonstrated by specific verbs like "be", "become", "have", "stand for", etc. And it can be divided into attributive relational process (it refers to: "A is one of the properties of B") and identifying relational process (it refers to: "A is the identity of B").

The example 5 undoubtedly includes relational process, more specifically, it belongs to identifying relational process, and the three same verbs "is" are the symbols. In this paragraph, Joe Biden emphasizes that the day he takes office is a day of democracy, history, hope, renewal and resolve, showing his great confidence and courage as a newly-installed president.

\section{The Analysis of Behavioral Process}

Example 6: "Here we stand, where 108 years ago at another inaugural, thousands of protestors tried to block brave women from marching for the right to vote. Today, we mark the swearing-in of the first woman in American history elected to national office -- Vice President Kamala Harris."

The behavioral process represents a process of behaving. In example 6, the word "vote" can be seen as a behavioral process, which refers to the basic right of common folks. By comparing the current situation with that of a hundred years ago, Biden points out the US has made great progress in liberty and equality.

\section{E. The Analysis of Verbal Process}

Example 7: "Don't tell me things can't change. Here we stand across the Potomac from Arlington National Cemetery, where heroes who gave the last full measure of devotion rest in eternal peace."

Example 8: "I ask every American to join me in this cause. Uniting to fight the common foes we face: anger, resentment, hatred, extremism, lawlessness, violence, disease, joblessness, hopelessness."

The verbal process means the process of information changing through talking, therefore, relevant verbs such as "talk", "speak", "tell" and "communicate" are always regarded as the symbols. In example 7 and 8, Biden uses "tell" and "ask" respectively to reflect his verbal processes. More specifically, he asks every American to join his cause and take action to fight the common foes they face such as anger, resentment, hatred, disease, joblessness, hopelessness, etc. Apparently, for him, it is extremely shameful and harmful to stick into the status quo. And what he really cares about is change and reform.

\section{F. The Analysis of Existential Process}

Example 9: "There is no accounting for what fate will deal you. There are some days when we need a hand. There are other days when we're called on to lend one. That is how we must be with one another."

The existential process indicates something exists or happens, therefore some verbs like "be", "arise" and "exist" are always included in it. In the example 9, it's clear that there are three existential processes that are used to state the existential facts. And they are represented by "there is", "there are" and "there are". Specifically speaking, in this paragraph, Joe Biden not only describes the complicated situation existing in the U.S. nowadays, but also encourages all American people to be tolerant and try to stand in the other people's shoes for a better future. In his eyes, only in this way can America be stronger and stronger.

\section{CONCLUSION}

According to the transitivity analysis mentioned above, the author finds some distinctive features in Joe Biden's inaugural address. First and foremost, Biden repeatedly points out the significance of unity, therefore he always calls on all American people to work together to fight disease like COVID-19, racism, violence and some other deep-rooted social inequities. In the second place, he is good at standing in ordinary people's shoes to express his concern about the current situation of the black people, female and ethnic minority communities, attempting to let them have a better living environment. Last but not least, he not only stresses the leading role of the U.S. but also puts forward that the great U.S. should also consolidate the relationship with all the allied countries. Clearly, in his opinion, good cooperation outweighs horrible split. In summary, through the transitivity analysis of Joe Biden's inaugural address from the perspective of Systemic Functional Grammar, people can have a comprehensive understanding of Joe Biden's political ideology, at the same time, people's ability of political discourse analysis will be improved. 


\section{REFERENCES}

[1] Beard, A. (2000). The Language of Politics. London: Routledge.

[2] Cabrejas, P. (2020). The Language of Recovery Metaphors in Obama's and Rajoy's Political Speeches. AB Revista Espanola De Linguistica Aplicada, 33, 27-54.

[3] Fairclough, N. (1989). Language and Power. New York: Longman.

[4] Halliday, M.AK. (1985). An Introduction to Functional Grammar. London: Edward Arnold Limited.

[5] Halliday, M.A.K. (2008). An Introduction to Functional Grammar (3rd ed.). Beijing: Foreign Language Teaching and Research Press.

[6] Hashim, S.S.M. (2015). Speech Acts in Selected Political Speeches. International Journal of Humanities and Cultural Studies, 2, 396-406.

[7] Lu, Ying. (2012). Zheng zhi yu pian zhong de ren ji yuan hua yu yan jiu-- yi 2012 nian guo wu yuan zheng fu gong zuo bao gao wei ge an [On interactional metadiscourse in political texts--a case study of Report on the Work of Government 2012]. Wai yu xue kan, (05):52-55.

[8] The full text of Joe Biden's inaugural address, from https://www.whitehouse.gov/briefing-room/speeches-remarks/2021/01/20/inaugural-address-by-president-joseph-r-biden-jr/.(R etrieved 10/10/2021)

[9] Wodak, R. (1989). Language, Power and Ideology: Studies in Political Discourse. Amsterdam: Benjamins.

[10] Zhang, Li \& Wang, Shaohua. (2021). Xi Jinping bo ao ya zhou lun tan 2018 nian nian hui kai mu yan jiang de ren zhi yu yong chan shi [A cognitive and pragmatic of Xi Jinping's speech at opening ceremony of Boao Forum for Asia in 2018]. Shan dong wai yu jiao xue, 42(01):31-39.

[11] Zhang, Quanfeng. (2016). Zheng zhi yan jiang yu pian de hu wen xing fen xi--yi lian he guo qi shi zhou nian da hui shang de yan jiang wei li [A study on the interextuality of political speech--a case study of the speeches on $70^{\text {th }}$ anniversary of UN]. Wai $y u$ xue kan, (05):51-53.

Qiujian Xiang was born in Sichuan, China in 1997. She is a graduate student and currently studying in the School of Foreign Languages and Literatures, Chongqing Normal University, Chongqing, China. Her research interests include critical discourse analysis and foreign language teaching. 